\title{
Sanguibacter marinus sp. nov., isolated from coastal sediment
}

\author{
Ying Huang, Xin Dai, Liang He, Ya-Nan Wang, Bao-Jun Wang, \\ Zhiheng Liu and Shuang-Jiang Liu
}

Correspondence

Shuang-Jiang Liu

shuangjiang@hotmail.com

\author{
State Key Laboratory of Microbial Resources, Institute of Microbiology, Chinese Academy of \\ Sciences, Beijing 100080, China
}

\begin{abstract}
A Gram-positive, coryneform bacterium, strain 1-19 ${ }^{\top}$, was isolated from coastal sediment from the Eastern China Sea. Phylogenetic analysis based on 16S rRNA gene sequences showed that the organism formed a robust clade with the type species of the genus Sanguibacter and displayed less than $97 \%$ gene sequence similarity. Phenotypic characteristics supported the assignment of this organism to the genus Sanguibacter. A range of biochemical features distinguished it from all other Sanguibacter species with validly published names. On the basis of a polyphasic taxonomical analysis, it is proposed that this bacterium is a novel species of Sanguibacter, for which the name Sanguibacter marinus sp. nov. is proposed. The type strain is $1-19^{\top}\left(=\right.$ CGMCC $1.3457^{\top}=$ JCM $\left.12547^{\top}\right)$.
\end{abstract}

The genus Sanguibacter was proposed by FernándezGarayzábal et al. (1995) and currently contains only three species with validly published names, Sanguibacter inulinus (Pascual et al., 1996), Sanguibacter keddieii and Sanguibacter suarezii (Fernández-Garayzábal et al., 1995). Members of this genus were isolated from the blood of healthy cows. Data on the occurrence of some other Sanguibacter strains in marine sediments or subsurface environments, such as oil reservoirs, are available from public databases, e.g. GenBank accession no. AB126692. During an investigation into the bacterial community of coastal sediment from the Eastern China Sea, a novel strain, $1-19^{\mathrm{T}}$, was isolated. The present study was designed to clarify the taxonomic position of this strain.

Strain $1-19^{\mathrm{T}}$ was isolated on plates of Difco marine agar 2216 (Difco) that had been seeded with a coastal sediment suspension and incubated at $30{ }^{\circ} \mathrm{C}$ for 5 days. The sediment sample was collected from the Eastern China Sea, Fujian province, China. The isolate was maintained on nutrient agar or trypticase soy agar (TSA; BBL) slants at $4{ }^{\circ} \mathrm{C}$ and as a glycerol suspension $(20 \%, \mathrm{v} / \mathrm{v})$ at $-20{ }^{\circ} \mathrm{C}$. Biomass for the chemical and molecular systematic studies was prepared as previously described (Huang et al., 2002) but modified by growing the strain for 3 days.

Cultural and morphological properties were examined by routine observation and with an electron microscope (FEI Quanta) after aerobic growth on TSA for 2-5 days at $30^{\circ} \mathrm{C}$.

Published online ahead of print on 3 June 2005 as DOI 10.1099/ ijs.0.63471-0.

The GenBank/EMBL/DDBJ accession number for the 16S rRNA gene sequence of Sanguibacter marinus $1-19^{\top}$ is AJ783958.
The ability of the strain to grow anaerobically was tested using the GENbox anaerobic system (bioMérieux) by incubating the TSA plate in an anaerobic jar. Flagellum staining was performed according to Heimbrook et al. (1989). General phenotypic tests were carried out following the procedures of Gordon et al. (1974) and Schofield \& Schaal (1981). Fermentation of carbohydrates was determined using the API $50 \mathrm{CH}$ kit (bioMérieux) according to the manufacturer's instructions and the reactions were recorded after incubation for $2,5,10$ and 15 days at $30^{\circ} \mathrm{C}$. Cell-wall peptidoglycan was prepared by extraction with a hot solution of $10 \%$ trichloroacetic acid, followed by treatment with trypsin in phosphate buffer ( $5 \mathrm{mg}$ trypsin in $10 \mathrm{ml} 0 \cdot 1 \mathrm{M}$ potassium phosphate buffer, $\mathrm{pH} 7 \cdot 9$ ) according to the rapid screening procedure described by Schleifer \& Kandler (1972). After two washes with distilled water, the pellet was hydrolysed with $4 \mathrm{M} \mathrm{HCl}$ at $100{ }^{\circ} \mathrm{C}$ for $60 \mathrm{~min}$. Amino acids and peptides in the hydrolysates were separated by two-dimensional ascending TLC on cellulose sheets using two solvent systems. The first direction was developed with 2-propanol/acetate $/ \mathrm{H}_{2} \mathrm{O}(75: 10: 15)$ and the second was developed using $\alpha$-picoline $/ 25 \% \mathrm{NH}_{4} \mathrm{OH} / \mathrm{H}_{2} \mathrm{O}(70: 2: 28)$. The developed cellulose sheets were stained by spraying with ninhydrin solution and heating at $70{ }^{\circ} \mathrm{C}$ for 5 min. Cellular menaquinones were extracted and purified as described by Collins (1985) and were analysed by HPLC (Wu et al., 1989). Mycolic acids were detected using the acid methanolysis procedure (Minnikin et al., 1975). Cellular fatty acids were extracted, methylated and analysed by GC using the Sherlock MIDI (Microbial Identification) system.

Genomic DNA of strain $1-19^{\mathrm{T}}$ was extracted according to the method of Marmur (1961). PCR amplification and 
sequencing of the $16 \mathrm{~S}$ rRNA gene were performed as described previously (Zhang et al., 2003). The nucleotide sequence was obtained automatically by using a DNA sequencer (model 377; Applied Biosystems) and software provided by the manufacturer. The $16 \mathrm{~S}$ rRNA gene sequence of strain $1-19^{\mathrm{T}}$ was aligned manually against corresponding sequences retrieved from the GenBank database using the CLUSTAL X 1.8 program (Thompson et al., 1997). Phylogenetic trees were inferred by using the least-squares (Fitch \& Margoliash, 1967), maximum-parsimony (Kluge \& Farris, 1969) and neighbour-joining (Saitou \& Nei, 1987) algorithms from the PHYLIP package version 3.5c (Felsenstein, 1993). Evolutionary distance matrices were generated as described by Kimura (1980). The resulting unrooted tree topologies were evaluated by bootstrap analysis (Felsenstein, 1985) of the neighbour-joining method based on 1000 resamplings. The PHYLIP package (Felsenstein, 1993) was used for all phylogenetic analyses. The DNA G $+\mathrm{C}$ content was determined using the thermal denaturation $\left(T_{\mathrm{m}}\right)$ method (Marmur \& Doty, 1962) with Escherichia coli $\mathrm{K}-12$ as the standard.

Comparison of the almost complete $16 \mathrm{~S}$ rRNA gene sequence of strain $1-19^{\mathrm{T}}$ (1486 nucleotides) with other sequences found by a BLAST search (Altschul et al., 1990) of the GenBank database showed that strain $1-19^{\mathrm{T}}$ formed a distinct phyletic line at the periphery of the evolutionary clade occupied by the genus Sanguibacter (Fig. 1). The taxonomic integrity of the strain and the three Sanguibacter species with validly published names was supported by the results obtained with all three tree-making algorithms and by a $100 \%$ bootstrap value based on the neighbour-joining method. The 16S rRNA gene sequence similarities between strain $1-19^{\mathrm{T}}$ and its nearest neighbours were $96.9 \%$ (S. inulinus), $96 \cdot 8 \%$ (S. keddieii) and $96 \cdot 7 \%$ (S. suarezii).
These values fall into the range recorded for many coryneform bacteria at the species level (Behrendt et al., 2002; Fernández-Garayzábal et al., 1995; Osorio et al., 1999; Pascual et al., 1996; Yassin et al., 2002). Similarity values between strain $1-19^{\mathrm{T}}$ and members of other genera were below $96 \cdot 0 \%$.

The chemotaxonomic data for strain $1-19^{\mathrm{T}}$ are consistent with its assignment to the genus Sanguibacter. The amino acid composition and cell-wall peptidoglycan pattern were the same as those of the type species of the genus, S. keddieii. Cells contained tetrahydrogenated menaquinones with nine isoprene units [MK-9 $\left(\mathrm{H}_{4}\right)$ ] as the predominant isoprenoid quinone. No mycolic acids were detected. The fatty acid profile consisted of anteiso- $\mathrm{C}_{15: 0}(46 \cdot 7 \%)$, anteiso- $\mathrm{C}_{15: 1} \mathrm{~A}$ $(17 \cdot 7 \%), \mathrm{C}_{16: 0}(10 \cdot 7 \%), \mathrm{C}_{15: 0}(9 \cdot 3 \%)$, iso- $\mathrm{C}_{16: 0}(3 \cdot 9 \%)$, $\mathrm{C}_{14: 0}(3 \cdot 9 \%)$, anteiso- $\mathrm{C}_{17: 0}(2 \cdot 4 \%)$, anteiso- $\mathrm{C}_{13: 0}(2 \cdot 3 \%)$, iso- $\mathrm{C}_{14: 0}(1 \cdot 3 \%), \mathrm{C}_{17: 0}(1 \cdot 0 \%)$ and iso- $\mathrm{C}_{15: 0}(0 \cdot 9 \%)$. The assignment of strain $1-19^{\mathrm{T}}$ to the genus Sanguibacter is also supported by other phenotypic characteristics (see species description). However, strain $1-19^{\mathrm{T}}$ can be easily distinguished from the Sanguibacter species with validly published names by a combination of biochemical features (Table 1).

It is evident from the genotypic and phenotypic data that strain $1-19^{\mathrm{T}}$ forms a distinct centre of taxonomic variation in the genus Sanguibacter. Therefore, it is proposed that the organism be classified as Sanguibacter marinus sp. nov.

\section{Description of Sanguibacter marinus sp. nov.}

Sanguibacter marinus (ma.ri'nus. L. masc. adj. marinus pertaining to the sea, where the isolate was found).

Cells are Gram-positive, non-endospore-forming, short, irregular, motile rods with sparse peritrichous flagella.

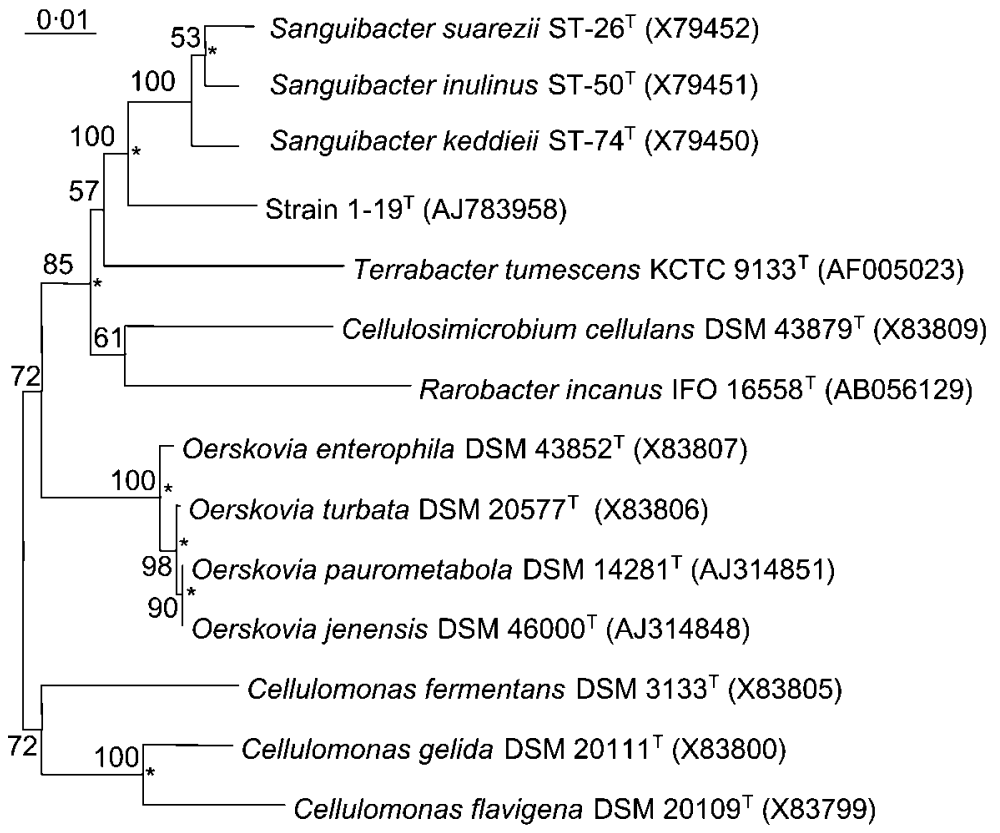

Fig. 1. Neighbour-joining tree (Saitou \& Nei, 1987) based on almost complete $16 \mathrm{~S}$ rRNA gene sequences showing the phylogenetic position of strain $1-19^{\top}$. Asterisks indicate branches that were also recovered using the least-squares (Fitch \& Margoliash, 1967) and maximum-parsimony (Kluge \& Farris, 1969) algorithms. The numbers at the nodes indicate the percentages of bootstrap support based on a neighbour-joining analysis of 1000 resampled datasets; only values over $50 \%$ are given. Bar, 0.01 substitutions per nucleotide position. 
Table 1. Differentiation of the species of the genus Sanguibacter based on phenotypic characteristics

Data for reference species from Fernández-Garayzábal et al. (1995) and Pascual et al. (1996). +, Positive; -, negative; V, variable.

\begin{tabular}{|lcccc|}
\hline Characteristic & S. marinus & S. inulinus & S. keddieii & S. suarezii \\
\hline Nitrate reduction & + & $\mathrm{V}^{*}$ & - & $\mathrm{V}$ \\
Acid production from: & & & + & - \\
N-Acetylglucosamine & - & + & + & $+^{*}$ \\
Amygdalin & - & + & + & + \\
Gentiobiose & - & + & $\mathrm{V}$ & - \\
Gluconate & - & + & + & + \\
Glycerol & - & + & - & - \\
Inulin & - & + & + & - \\
5-Ketogluconate & - & + & - & + \\
D-Lyxose & - & $\mathrm{V}$ & + & + \\
D-Mannitol & - & + & + & - \\
D-Melibiose & - & + & + & - \\
Methyl $\alpha$-D-glucoside & $+*$ & + & + & + \\
Methyl $\alpha$-D-mannoside & - & $\mathrm{V}$ & + & + \\
Methyl $\beta$-D-xyloside & - & + & + & + \\
L-Rhamnose & - & + & + & - \\
D-Ribose & - & - & + & + \\
D-Sorbitol & - & + & + \\
D-Turanose & & & + & \\
\hline
\end{tabular}

${ }^{\star}$ Weak or delayed reaction.

Colonies are circular, convex with entire edges and pale yellow. Diffusible pigments are not produced. Growth occurs under aerobic and anaerobic conditions on TSA medium. Catalase-positive and oxidase-negative. Growth occurs at $15-37^{\circ} \mathrm{C}$ (optimum $25-30{ }^{\circ} \mathrm{C}$ ), $\mathrm{pH} 5 \cdot 5-9 \cdot 0$ and 0-7\% (w/v) $\mathrm{NaCl}$. No growth at $42{ }^{\circ} \mathrm{C}$ and $10 \% \mathrm{NaCl}$. Citrate is not utilized. Aesculin, gelatin and starch are hydrolysed, but casein, cellulose and Tween 80 are not. Methyl red and indole tests are positive, but VogesProskauer test is negative. Acid is produced from L-arabinose, arbutin, D-cellobiose, D-fructose, D-galactose, D-glucose, glycogen, D-lactose, D-maltose, D-mannose, salicin, D-sucrose, D-trehalose and D-xylose, but not from D-adonitol, D-arabinose, DL-arabitol, dulcitol, meso-erythritol, DL-fucose, inositol, 2-ketogluconate, D-melezitose, D-raffinose, L-sorbose, D-tagatose, xylitol or L-xylose. Additional biochemical characteristics are given in Table 1 . The cell-wall peptidoglycan type is the same as that of S. keddieii. The menaquinones are MK-9 $\left(\mathrm{H}_{4}\right)$ and MK$9\left(\mathrm{H}_{6}\right)$ (peak area ratio, $10 \cdot 4: 1$ ). The cellular fatty acid profile consists mainly of anteiso methyl-branched type anteiso- $\mathrm{C}_{15}$ and straight-chain saturated components. The DNA G $+\mathrm{C}$ content is $73.4 \mathrm{~mol} \%$ ( $T_{\mathrm{m}}$ method).

The type strain, $1-19^{\mathrm{T}}\left(=\mathrm{CGMCC} 1.3457^{\mathrm{T}}=\mathrm{JCM} 12547^{\mathrm{T}}\right)$, was isolated from coastal sediment collected in the Fujian province of China.

\section{Acknowledgements}

This research was supported by a grant from the National Nature Science Foundation of China (project no. 30230010). We are grateful to Professor Dr Nian-Zhi Jiao at Xiamen University in Fujian province for his kind provision of the coastal sediment samples. We are also grateful to Professor Dr H. G. Trüper for his help with the specific epithet.

\section{References}

Altschul, S. F., Gish, W., Miller, W., Myers, E. W. \& Lipman, D. J. (1990). Basic local alignment search tool. J Mol Biol 215, 403-410.

Behrendt, U., Ulrich, A., Schumann, P., Naumann, D. \& Suzuki, K. (2002). Diversity of grass-associated Microbacteriaceae isolated from the phyllosphere and litter layer after mulching the sward; polyphasic characterization of Subtercola pratensis sp. nov., Curtobacterium herbarum sp. nov. and Plantibacter flavus gen. nov., sp. nov. Int J Syst Evol Microbiol 52, 1441-1454.

Collins, M. D. (1985). Isoprenoid quinone analysis in classification and identification. In Chemical Methods in Bacterial Systematics, pp. 267-287. Edited by M. Goodfellow \& D. E. Minnikin. London: Academic Press.

Felsenstein, J. (1985). Confidence limits on phylogenies: an approach using the bootstrap. Evolution 39, 783-791.

Felsenstein, J. (1993). PHYLIP (phylogenetic inference package) version 3.5c. Department of Genome Sciences, University of Washington, Seattle, WA, USA. 
Fernández-Garayzábal, J. F., Dominguez, L., Pascual, C., Jones, D. \& Collins, M. D. (1995). Phenotypic and phylogenetic characterization of some unknown coryneform bacteria isolated from bovine blood and milk: description of Sanguibacter gen. nov. Lett Appl Microbiol 20, 69-75.

Fitch, W. M. \& Margoliash, E. (1967). Construction of phylogenetic trees: a method based on mutation distances as estimated from cytochrome $c$ sequences is of general applicability. Science 155, 279-284.

Gordon, R. E., Barnett, D. A., Handerhan, J. E. \& Pang, C. H. N. (1974). Nocardia coeliaca, Nocardia autotrophica and the nocardin strain. Int J Syst Bacteriol 24, 54-63.

Heimbrook, M. E., Wang, W. L. \& Campbell, G. (1989). Staining bacterial flagella easily. J Clin Microbiol 27, 2612-2615.

Huang, Y., Wang, L., Lu, Z., Hong, L., Liu, Z., Tan, G. Y. A. \& Goodfellow, M. (2002). Proposal to combine the genera Actinobispora and Pseudonocardia in an emended genus Pseudonocardia, and description of Pseudonocardia zijingensis sp. nov. Int J Syst Evol Microbiol 52, 977-982.

Kimura, M. (1980). A simple method for estimating evolutionary rates of base substitutions through comparative studies of nucleotide sequences. J Mol Evol 16, 111-120.

Kluge, A. G. \& Farris, F. S. (1969). Quantitative phyletics and the evolution of anurans. Syst Zool 18, 1-32.

Marmur, J. (1961). A procedure for the isolation of deoxyribonucleic acid from microorganisms. J Mol Biol 3, 208-218.

Marmur, J. \& Doty, P. (1962). Determination of base composition of deoxyribonucleic acid from its denaturation temperature. J Mol Biol 5, 109-118.

Minnikin, D. E., Alshamaony, L. \& Goodfellow, M. (1975). Differentiation of Mycobacterium, Nocardia and related taxa by thin-layer chromatographic analysis of whole-organism methanolysates. J Gen Microbiol 88, 200-204.

Osorio, C. R., Barja, J. L., Hutson, R. A. \& Collins, M. D. (1999), Arthrobacter rhombi sp. nov., isolated from Greenland halibut (Reinhardtius hippoglossoides). Int J Syst Bacteriol 49, 1217-1220.

Pascual, C., Collins, M. D., Grimont, P. A., Dominguez, L. \& Fernández-Garayzábal, J. F. (1996). Sanguibacter inulinus sp. nov. Int J Syst Bacteriol 46, 811-813.

Saitou, N. \& Nei, M. (1987). The neighbor joining method: a new method for constructing phylogenetic trees. Mol Biol Evol 4, 406425.

Schleifer, K. H. \& Kandler, O. (1972). Peptidoglycan types of bacterial cell walls and their taxonomic implications. Bacteriol Rev 36, 407-477.

Schofield, G. M. \& Schaal, K. P. (1981). A numerical taxonomic study of members of the Actinomycetaceae and related taxa. J Gen Microbiol 127, 237-259.

Thompson, J. D., Gibson, T. J., Plewniak, F., Jeanmougin, F. \& Higgins, D. G. (1997). The CLUSTAL X windows interface: flexible strategies for multiple sequence alignment aided by quality analysis tools. Nucleic Acids Res 25, 4876-4882.

Wu, C., Lu, X., Qin, M., Wang, Y. \& Ruan, J. (1989). Analysis of menaquinone compound in microbial cells by HPLC. Microbiology (English translation of Mikrobiologiia) 16, 176-178.

Yassin, A. F., Steiner, U. \& Ludwig, W. (2002). Corynebacterium appendicis sp. nov. Int J Syst Evol Microbiol 52, 1165-1169.

Zhang, D., Yang, H., Zhang, W., Huang, Z. \& Liu, S.-J. (2003). Rhodocista pekingensis sp. nov., a cyst-forming phototrophic bacterium from a municipal wastewater treatment plant. Int J Syst Evol Microbiol 53, 1111-1114. 